summary of the British Thoracic Society Guidelines for the management of community acquired pneumonia in adults: 2009 update. Endorsed by the Royal College of General Practitioners and the Primary Care Respiratory Society UK. Prim Care Respir J 2010;19:21-7. http://dx.doi.org/10.4104/pcrj.2010.00014

9. Bauer TT, Ewig S, Marre R, Suttorp N, Welte T. CRB-65 predicts death from community-acquired pneumonia. J Intern Med 2006;260:93-101. http://dx.doi.org/10.1111/j.1365-2796.2006.01657.x

10. Bont J, Hak E, Hoes AW, Macfarlane JT, Verheij TJ. Predicting death in elderly patients with community-acquired pneumonia: a prospective validation study reevaluating the CRB-65 severity assessment tool. Arch Intern Med 2008; 168:1465-8. http://dx.doi.org/10.1001/archinte.168.13.1465

11. Francis NA, Cals JW, Butler CC, Hood K, Verheijc T, Little P, Goossense H, Coenen $S$ on behalf of the GRACE Project Group. Severity assessment for lower respiratory tract infections: potential use and validity of the CRB-65 in primary care. Prim Care Respir J 2010;21:65-70. http://dx.doi.org/10.4104/pcrj.2011.00083

12. Bont J, Hak E, Hoes AW, Schipper M, Schellevis FG, Verheij TJ. A prediction rule for elderly primary-care patients with lower respiratory tract infections. Eur Respir $J$ 2007;29:969-75. http://dx.doi.org/10.1183/09031936.00129706

\title{
Asthma deaths: we need to identify risk factors early and construct at-risk asthma registers
}

\section{See linked article by Anagnostou et al. on pg 71}

\section{*Paul Stephenson ${ }^{\mathrm{a}}$, Michael Shields ${ }^{\mathrm{b}}$}

a Honorary Clinical Research Fellow, Allergy and Respiratory Research Group, Centre for Population Health Sciences, The University of Edinburgh, Edinburgh, UK; Former Lead GP, UK Eastern Region Confidential Enquiry into asthma deaths

b Professor of Child Health \& Consultant Paediatrician (Respiratory), Centre for Infection \& Immunity, Queens University Belfast, N Ireland

*Correspondence: Dr Paul Stephenson, The Christmas Maltings and Clements Practice, Haverhill, Suffolk, CB9 8HF, UK Tel: c/o +44 (0)1461 600639 Fax: c/o +44 (0)1461 207819 E-mail: paul.stephenson@gp-d83012.nhs.uk

Studies into asthma deaths began in the 1960s in response to increasing mortality rates. ${ }^{1}$ Since then, various Confidential Enquiries and related reports from around the world ${ }^{2-7}$ have highlighted many factors - both medical management- and patient-related - which increase the risk of death in patients with asthma. Many of these are now well recognised, and have been incorporated into nationa $\left.\right|^{8}$ and international ${ }^{9}$ guidelines. The longest running Confidential Enquiry is based in the eastern region of the UK, ${ }^{6,7}$ and in this issue of the $P C R J$ Anagnostou et al. report on 20 deaths in children aged 17 or under (median age 11.5 years) which occurred between 2001 and 2006. ${ }^{10}$ The authors have done a great service in reminding us that people still die from asthma, and that some of these deaths - albeit rarely occur in children. The paper is also timely, since the 12-month UK Royal College of Physicians National Review of Asthma Deaths led by Mark Levy started on 1st February 2012.

Paediatric asthma deaths in the UK peaked in the mid-1960s with a mortality rate of 10 per million/year in the under-5s and 14 per million/year in children aged 5-14; rates then dropped to 2 per million/year in both age groups between 1990-2000. ${ }^{11}$ The eastern region of the UK has a population of approximately 5.25 million. Of the 20 childhood asthma deaths between 2001 and 2006, ${ }^{10}$ none of these were in children aged under 5; there were 13 deaths in the 5 14 age group, and seven in children aged 15-17. The absence of any deaths in the under-5s may simply be due to chance and the relatively small numbers involved, but our improved understanding (over the last 15 years) of the different diagnostic categories and more selective use of the term 'asthma' in this age group ${ }^{12,13}$ may also be a contributory factor.

Confidential enquiries have inherent methodological limitations; they are uncontrolled, retrospective and observational, and are more akin to audit or significant event analysis. Therefore the data need to be interpreted with caution. Nevertheless, the authors highlight a number of important points for clinicians and policy makers. ${ }^{10}$ Nine of the 20 children who died had mild to moderate asthma, 10 had severe asthma, and one had no previous diagnosis. This is a salutary reminder that death can occur in patients with mild or moderate disease (albeit that the risk of death in children with severe asthma is higher since the proportion with severe disease is much smaller ${ }^{14}$ ); seven out of the nine suffered sudden death, one was unwell for three days after a thunderstorm, and one suffered possible anaphylaxis after exposure to guinea pig. ${ }^{10}$ Two-thirds had documented poor adherence, and denial (either on the part of the patient or the parents) was a factor in two. The challenges of managing this patient group will be hard to address; most children who died did not have a written asthma action plan, and perhaps more attention should be given to this aspect of education - with more focus on acute crisis management - when dealing with someone with 'less troublesome' asthma.

A strength of this Enquiry is the emphasis on elucidating allergic factors involved in the patient's death; 13 of the 20 children had a clinical picture consistent with atopy, but only three had had formal allergy testing in an allergy clinic. 50\% died between June and August, and three deaths occurred during a thunderstorm. Furry pet animal dander was thought to be the trigger for four children. Together, these data highlight the need for clinicians to take a detailed allergy history (focussing on a range of external triggers) followed by appropriate testing when indicated. Unfortunately, we cannot tell whether prior allergy testing and knowledge about these allergies could have modified behaviour and prevented the deaths. The fact that half the deaths occurred in June to August suggests that clinicians should optimise therapy when the danger season approaches and ensure adherence with inhaled corticosteroid (ICS) treatment at appropriate doses. September and early October were not associated with high deaths, but there is an annual peak in asthma hospitalisation for younger children at this time ${ }^{15}$ which is 
probably related to viral respiratory infections ${ }^{16}$ and parents failing to restart ICS after the summer holidays.

Many of the other risk factors have been highlighted previously. ${ }^{2-7}$ Five of the 10 children with severe asthma were being managed solely in primary care and none of them had a written asthma management plan. In $40 \%$ of cases, asthma follow-up was considered inadequate. Nine children were poorly compliant with medication, and six (30\%) had poorly controlled asthma despite good compliance - i.e. they were being undertreated. $60 \%$ had psychosocial or behavioural factors which contributed to their death; half of these came from dysfunctional families with domestic problems. In six cases, children were on long-acting $\beta_{2}$-agonist (LABA) inhalers but not on ICS - two had no ICS prescribed and four were not taking their separate ICS inhaler. The Food and Drug Administration (FDA) in the USA now recommends that only combination ICS/LABA inhalers should be prescribed in paediatric and adolescent patients who require LABA to be added to ICS treatment. ${ }^{17}$

We have known for a number of years what the clinical management failings are which contribute to asthma death, ${ }^{2-7}$ that most fatal attacks are not of severe sudden onset (therefore the opportunity for intervention exists), and we know what factors put an asthma patient 'at-risk'. ${ }^{7.8}$ A systematic review on promoting the use of asthma management plans highlighted several ways in which their use could be encouraged. ${ }^{18}$ A retrospective pilot study in primary care showed reductions in hospital admissions, out-of-hours attendances, courses of oral steroids and healthcare costs in patients on at-risk asthma registers compared to controls. ${ }^{19} \mathrm{~A}$ randomised controlled trial to be published soon will show that patients on atrisk asthma registers have more courses of oral steroids and less hospitalisations than matched controls (Prof D Price, personal communication).

Children placed on the at-risk asthma register would include those with known severity-based risk factors:

- A previous severe exacerbation (admission in last year, admission to the intensive care unit)

- Previous brittle / anaphylactic reactions especially if associated with food allergy

- Those already known to have difficult-to-treat asthma (BTS/SIGN steps 4 and $5^{8}$ )

Until more is understood about the reasons why asthma death is more common in children with psychosocial problems (including those who fail to attend for appointments) such children should also be placed on at-risk registers even if they only have mild disease.

Children on the at-risk asthma register could have targeted management that promotes the use of asthma action plans ${ }^{18}$ which include the best course of action to treat an attack, with more focussed attention on non-adherence, allergy assessment and trigger avoidance. LABAs should only be prescribed in a combination ICS/LABA inhaler to prevent poor ICS adherence. Undertreatment with ICS and oral steroids, which also puts patients at risk, could be identified and avoided.

We believe that at-risk asthma registers will make a difference, and that they should be constructed in every primary care practice worldwide. Now is the time for action.
Conflicts of interest PS is Joint Editor-in-Chief of the PCRJ, but was not involved in the editorial review of, nor the decision to publish, this article. MS declares that he has no conflicts of interest in relation to this article.

Commissioned article; not externally peer-reviewed; accepted 15th January 2012; online 17th January 2012

(c) 2012 Primary Care Respiratory Society UK. All rights reserved

http://dx.doi.org/10.4104/pcrj.2012.00007

Prim Care Respir J 2012; 21(1): 13-14

\section{References}

1. Speizer FE, Doll R, Heaf P. Observations on recent increase in mortality from asthma. BMJ 1968;1:335-9. http://dx.doi.org/10.1136/bmj.1.5588.335

2. Sears MR, Rea HH, Beaglehole RG, et al. Asthma mortality in New Zealand: a two year national study. NZ Med J 1985;98:271-5.

3. Bucknall CE, Slack R, Godley CC, et al. Scottish Confidential Enquiry into Asthma Deaths (SCIAD), 1994-6. Thorax 1999;54:978-84.

http://dx.doi.org/10.1136/thx.54.11.978

4. Burr ML, Davies BH, Hoare A et al. A confidential enquiry into asthma deaths in Wales. Thorax 1999;54:985-9. http://dx.doi.org/10.1136/thx.54.11.985

5. Barton CA, McKenzie DP, Walters EH, Abramson MJ. The Victorian Asthma Mortality Study Group. Interactions between psychosocial problems and management of asthma: who is at risk of dying? J Asthma 2005;42:249-56. http://dx.doi.org/10.1081/JAS-200057881

6. Wareham NJ, Harrison BDN, Jenkins PF, Nicholls J, Stableforth DE. A district confidential enquiry into deaths due to asthma. Thorax 1993;48:1117-20. http://dx.doi.org/10.1136/thx.48.11.1117

7. Harrison B, Stephenson P, Mohan G, Nasser S. An ongoing Confidential Enquiry into asthma deaths in the Eastern Region of the UK, 2001-2003. Prim Care Respir J 2005;14(6):303-13. http://dx.doi.org/10.1016/j.pcrj.2005.08.004

8. British Guideline on the Management of Asthma. A national clinical guideline Thorax 2008;63(Suppl IV);iv1-iv121. http://dx.doi.org/10.1136/thx.2008.097741

9. From the Global Strategy for Asthma Management and Prevention, Global Initiative for Asthma (GINA) 2010. Available from: http://www. ginasthma.org/. Accessed 7th January 2012

10. Anagostou K, Harrison B, lles R, Nasser S. Risk factors for childhood asthma deaths from the UK Eastern Region Confidential Enquiry, 2001-2006. Prim Care Respir J 2012;21:71-77. http://dx.doi.org/10.4104/pcrj.2011.00097

11. Gupta R, Strachan D. Asthma and allergic diseases (The health of children and young people, chapter 7). Office for National Statistics, March 2004.

12. Bush A. Diagnosis of asthma in children under five. Prim Care Respir J 2007;16:715. http://dx.doi.org/10.3132/pcrj.2007.00001

13. Martinez FD, Wright AL, Taussig LM, Holberg CJ, Halonen M, Morgan WJ, Group Health Medical Associates. Asthma and wheezing in the first six years of life. N Engl J Med 1995;332:133-8. http://dx.doi.org/10.1056/NEJM199501193320301

14. Lai CKW, Beasley R, Crane J, Foliaki S, Shah J, Weiland S, the ISAAC Phase Three Study Group. Global variation in the prevalence and severity of asthma symptoms: Phase Three of the International Study of Asthma and Allergies in Childhood (ISAAC) Thorax 2009;64:476-83. http://dx.doi.org/10.1136/thx.2008.106609

15. Julious SA, Osman LM, Jiwa M. Increases in asthma hospital admissions associated with the end of the summer vacation for school-age children with asthma in two cities from England and Scotland. Public Health 2007;121(6):482-4. http://dx.doi.org/10.1016/j.puhe.2006.11.011

16. Johnston SL, Pattermore PK, Sanderson G et al. The relationship between upper respiratory infection and hospital admissions for asthma: a time-trend analysis. Am J Resp Crit Care Med 1996;154:654-60.

17. Chowdhury BA, Dal Pan G. The FDA and safe use of long-acting best-agonists in the treatment of asthma. N Engl J Med 2010;362:1169-71. http://dx.doi.org/10.1056/NEJMp1002074

18. Ring N, Malcolm C, Wyke S, et al. Promoting the use of Personal Asthma Action Plans: a systematic review. Prim Care Respir J 2007;16:271-83. http://dx.doi.org/10.3132/pcri.2007.00049

19. Noble MJ, Smith JR, Windley J. A controlled retrospective pilot study of an 'at-risk asthma register' in primary care. Prim Care Respir J 2006;15:116-24. http://dx.doi.org/10.1016/j.pcri.2006.01.002 